\title{
Effect of Additional Air Supply for Combustion of Straight Vegetable Oil Blends on Performance of Mini Hot Water Generator
}

\author{
K. ARUMUGAM*, P. MARAN**, K. ARAVINDHAN***, T. SORNAKUMAR**** \\ *Assistant Professor, Dept. of Mechanical Engineering, University College of Engineering Ramanathapuram - 623 513, \\ India, E-mail: arumugamk_in@yahoo.co.in \\ **Assistant Professor, Dept. of Mechanical Engineering, Thiagarajar College of Engineering, Madurai - 625 015, India, \\ E-mail: pmmech@tce.edu \\ ***Design Engineer, TCS, Pune - 411 006, India, E-mail: aravittm@gmail.com \\ ****Professor, Dept. of Mechanical Engineering, Thiagarajar College of Engineering, Madurai - 625 015, India, \\ E-mail:tskmech@tce.edu
}

cross $^{\text {ref }}$ http://dx.doi.org/10.5755/j01.mech.24.2.19783

\section{Introduction}

The increasing industrialization and motorization of the world has led to a steep rise for the demand of petroleum-based fuels. Petroleum-based fuels are obtained from finite reserves and these limited resources are massively concentrated in certain regions of the world. Therefore, those countries not owning these fuel assets are facing energy/foreign exchange crisis, mainly due to the import of crude petroleum. It has become necessary to look for alternate fuels which can be produced from resources existing nearby regions. The growing energy needs in developing countries, especially in rural areas, give more and more importance to the use of alternate fuels in general and to vegetable oils in particular. This trend has been accelerated by the declining petroleum resources and the role that bio fuels could contribute to reduction of greenhouse gases emission.

Many studies on the characteristics of vegetable oils or their derivatives and their use in diesel engines have been made over the last four decades. The use of vegetable oil in oil burners has been studied by many researchers for the last two decades. Vegetable oils can be used as alternative fuels because they are biodegradable, non-toxic, and clean fuels. Vegetable oils and their derivatives substantially reduces sulfur, carbon monoxide, polycyclic aromatic hydrocarbons, smoke and particulate emissions. Vegetable oils like karanja oil, rapeseed oil, rice bran oil, cottonseed oil, sunflower oil and jatropha oil are being tested by many researchers in diesel engines.

The possibility of using the vegetable oil in raw form and blended form with diesel or biodiesel is being explored in gas turbine and boiler. The researchers have focussed on the selection of fuel properties, techniques for improving the properties of raw fuel, injection methods, mechanism, pattern, injector design, combustion chamber modification, additives, secondary air and optimum fuel air mixture, emissions etc.

Raslavičius et al. [1] studied about the possibilities of biofuel utilization in the transport sector of Lithuania. The $\mathrm{CO}_{2}$ emission is increasing in Lithuania and this rise could be delivered from all transport subsectors. The emissions of greenhouse gases, air and soil pollution. Raslavicius et al. [2] discussed about the formative breakthrough attitude towards a possible path of Lithuania's sustainable development by utilizing the rape seed oil and its biodiesel for combined heat and power applications.

Zhou et al. [3] interested in biofuel studied and explained increased interest in biofuels globally due to energy security and climate change. According to the IEA report, in 2006 biofuels paid $1 \%$ of the world's transport fuel consumption, but in 2030 this could rise to $4 \%$. The production of biodiesel in- creased by $295 \%$. Phan et al. [4] projected that bioethanol/ biodiesel might replace nearly $10 \%$ of diesel fuel consumption within Europe and at Southeast Asia's 5\% of total fuel crisis.

Jayed et al. [5] elucidated Thailand's and Indonesia are mainly depending on molasses and cassava and sugarcane for vegetable oil and bio-ethanol production. Whereas Malaysia's making is completely absorbed only in palm diesel, this makes it more susceptible to petroleum and palm oil costs. Still, palm oil's resourceful applications have made it most wanted after vegetable oil in the world. A consequent growth of biofuel plants has leaded a sustainable energy security through biodiesel.

Sanz Requena et al. [6] and Demirbas el al [7] explained the benefits include greenhouse gas reductions, biodegradability, diversification of fuel, sustainability and an additional market for agricultural products. Sustainability should gradually confirm that only advanced biofuels are available for consumers. Sustainability of edible oil can be achieved by mass production of vegetable oil by $20-25 \%$ of additional cultivation energy production. The waste or mix oil collected during the extraction of oil from the sunflower oil seed and rice bran oil seed will also improve the sustainability of energy generation from straight vegetable oil. The worthy energy balance joint with a good $\mathrm{CO}_{2}$ balance endorses vegetable oils as ecologicaleconomical fuels for energy production.

Alonso et al. [8] studied the properties of sunflower, rape seed and soya oil. Properties and chemical compositions of vegetable oil with various proportions with diesel were compared with that of diesel. Singh et al. [9], Yathish et al. [10] and Maran et al. [11] prepared biodiesel of vegetable oil by transesterification process with the aid of methanol and $\mathrm{NaOH} / \mathrm{KOH} / \mathrm{H}_{2} \mathrm{SO}_{4}$. Properties of Jatropha and custard apple biodiesel were compared with the properties of diesel. Calorific value of vegetable oil and its biodiesel is lower compared to diesel, but biodiesel has relatively higher viscosity, flash and pour points than that of diesel.

Esteban et al. [12] and Kang et al. [13] studied the effect of preheating on properties of different vegetable oils (VOs) including biodiesel of Rape Seed (RJ), Crude Jatropha (CJ), Sun Flower (SF), Soy Bean (SB), palm, corn and grape seed oils. Research showed that VO is to be preheated to a temperature between $90^{\circ} \mathrm{C}$ to $120^{\circ} \mathrm{C}$ minimally to obtain the properties of biodiesel very close to diesel. The authors also investigated the combustion performance and emission characteristics by adjusting the temperature of VO.

Glaude et al. [14] and Chong et al. [15] investigated the combustion of rapeseed Methyl Ester (RME) and 
Jet-A1 fuel in $6 \mathrm{~kW}$ gas turbine, where the main air was preheated to the temperature of $350^{\circ} \mathrm{C}$ at atmospheric pressure. Jet-A1 fuel droplet characteristics such as droplet size, droplet number, density and volume flux were investigated. Czisch et al. [16] developed a rotary atomizer combined with the external mixing gas atomizer. The combined atomizer setup reduces the droplet size up to 210 microns at constant air-fuel ratio. Fan et al. [17] examined a spray of Crude Jatropha oil (CJO), Jatropha methyl ester (JME) and diesel in an air-assist pressure-swirl atomizer. The results showed that atomizer performance depends on the quality of liquid cone, which affects the physical and flow properties.

Raslavicius et al. [18] compared the first generation biofuels with diesel oil and produced power of $340 \mathrm{~kW}$ from rapeseed oil methyl ester, which produces the great energy performances and lower emission than that of conventional diesel. Vaitillingom et al. [19] conducted experiments in a $260 \mathrm{~kW}$ boiler for different spray nozzles. The properties of vegetable oil and domestic fuel oil were investigated by adjusting the position of the flame stabilizer, opening of air valve, temperature at tip of spray nozzle $\left(80^{\circ} \mathrm{C}\right.$ to $\left.150^{\circ} \mathrm{C}\right)$ and oil injection pressure. It was also noted that there was no ignition under $80^{\circ} \mathrm{C}$ and $2 \mathrm{MPa}$. Yao et al. [20] studied the influence of viscosity on spray parameters, by mixing of water and glycerol with various volume ratios. The structure of spray was correlated with the viscosity of fuel. Alonso et al. [21] investigated the use of rapeseed oil and diesel mixtures. The viscous effect of the fuel restricted the percentage of rape seed oil in the mixture below $30 \%$. Increase of injection pressure, causes increase in $\mathrm{CO}$ emission and decrease in emission of $\mathrm{SO}_{2}$ and $\mathrm{CO}_{2}$.

Bazooyar et al. [22] made combustion of rape seed, corn, sunflower, soy bean, olive and rice bran oils in a nonpressurized, water cooled combustion chamber, and estimated the performance and gas emissions. Thermal efficiency was lower in the range of $12 \%$ to $21 \%$ at a low fuel pressure of 8.274 bar, and $21 \%$ to $26 \%$ at higher fuel pressure of 19.305 bar, for different fuel blends.

Ghorbani et al. [23] compared the combustion efficiency and flue gas emission for biodiesels of soy bean oil and sun flower oil at two energy levels i.e., $219 \mathrm{~kJ} / \mathrm{hr}$ and $249 \mathrm{~kJ} / \mathrm{hr}$. Combustion efficiency decreases as air flow is increased. Soy bean bio diesel was more efficient than sunflower biodiesel at higher energy rate. $20 \%$ blend of Soy bean biodiesel produces little lower combustion efficiency than that of diesel but $\mathrm{CO}_{2}$ and $\mathrm{SO}_{2}$ emission reduces by $4.2 \%$ and $7 \%$ respectively.

Demirbas [1] tested particulate matter in CI engine it was found that the PM level for $20 \%$ biodiesel reduced about $8.9 \%$ and $100 \%$ biodiesel reduced about $55.3 \%$. Alonso et al. [8] found that the particulate matter in vegetable oil is reduced to $65 \%$ than petroleum diesel. Dizayi et al. [24] identified about the PM concern for vegetable oil it lies between PM 10 to PM 2.5 , (i.e. diameter of micro meters).PM emissions for vegetable oil blends were lower than diesel up to $65-75 \%$.

Daho et al. [25] studied the influence of combustion parameters such as equivalence ratio and fuel pressure on combustion and emission performance of blends of 10 to $70 \%$ refined cottonseed oil (RCO) with domestic fuel-oil (DFO) in a non-modified DFO burner.

From the available literatures, it is clear that a very few experimental studies have been reported for the investigation on combustion of straight vegetable oils and blends in burners used in furnaces of boilers. Further, limited attempts have been made to improve the mixing of fuel and oxidizer to improve the performance characteristics of fuel blend with maximum percentage of straight vegetable oils. The present study focuses on investigating the effect of additional air supply for the combustion of straight vegetable oil on improving thermal efficiency of hot water generator and lowering the emissions.

\section{Experimental setup}

The schematic diagram of the experimental setup used in the present study is shown in Fig. 1. The setup has been designed and developed to conduct experiments to study the combustion performance and emission trend by using straight vegetable oil and its blends with diesel. The set up consists of a commercial oil burner, hot water generator and an additional air supply system.

The mini hot water generator is a fire tube boiler having $35 \mathrm{~kg}$ water capacity. It has four fire tubes of diameter $38 \mathrm{~mm}$, passing the hot gases from the furnace to the smoke tube heating the water in the boiler drum. The main drum and furnace have been insulated by using glass wool and asbestos rope and covered with heat resistance sheet. The commercial oil burner is of swirl type burner with a capacity of $150 \mathrm{~g} / \mathrm{min}$, which atomizes the liquid oil into tiny particles using forced air from the centrifugal blower. The main air is supplied by a blower having the capacity of $0.0472 \mathrm{~m}^{3} / \mathrm{s}$.

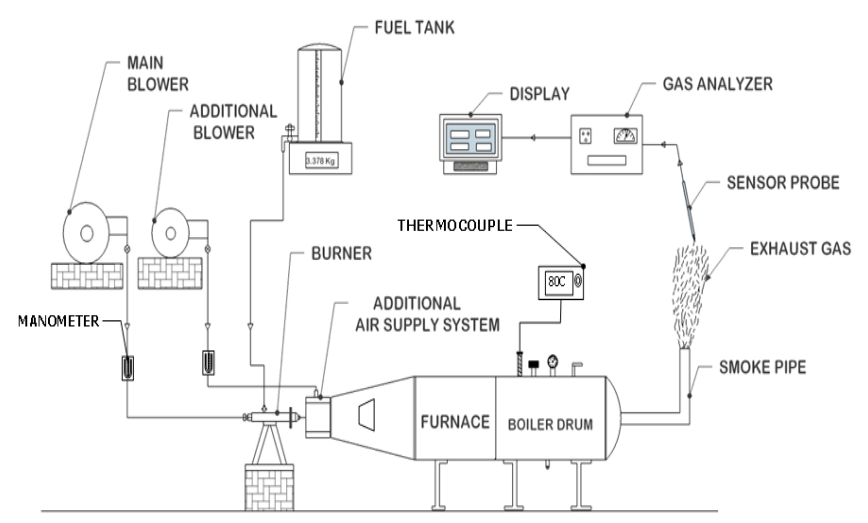

Fig. 1 Experimental setup of hot water generator

The volume flow rates of main and additional air are measured by using orifice meters and the mass flow rate is calculated using local pressure and temperature. The fuel is supplied from the overhead fuel tank, and the mass flow rate of fuel is measured with the help of a digital weighing machine. The thermocouples are fixed to measure the temperatures of water and flue gases. Thermocouple sensors were located from the top of the shell so that the sensor end is always dipped into water in the boiler shell and not touching the tube or side wall.

Thermocouples used are of Chromel/Alumel K-type, $\left(0-1200^{\circ} \mathrm{C}\right)$ with the accuracy of $\pm 0.5 \%$ of measured value and resolution of $\pm 0.1^{\circ} \mathrm{C}$.A CRYPTON 290-EN2 type gas analyser has been used to measure the exhaust emissions from the hot water generator setup. The analyser has an accuracy of $\pm 5 \%$ of measured values of $\mathrm{HC}, \mathrm{NO}_{x}, \mathrm{CO}$ and $\mathrm{CO}_{2}$ with a resolution of $1 \mathrm{ppm}$ for $\mathrm{HC}$ and $\mathrm{NO}_{\mathrm{x}}$ and of $0.1 \%$ for $\mathrm{CO}$ and $\mathrm{CO}_{2}$. For $\mathrm{O}_{2}$ accuracy is $\pm 0.2 \%$ of measured value and resolution of $0.1 \%$. The range of gas analyser has been presented in Table 1 .

\section{Experiments and results}

Experiments have been conducted to investigate the 
combustion performance and emission levels during the combustion of straight vegetable oils blended with diesel in a hot water generator with additional (WA) air supply and without additional (WOA) air supply. The details of fuel blends used in the present study are presented in Table 2.

Each fuel blend is named with the name of the vegetable oil and its percentage in the blend. For example, $25 \%$ sunflower oil in the blend is named as SFVO 25 and $50 \%$ rice bran oil in the blend is named as RBVO 50. For each case, thermal efficiency and emission levels have been found and compared in the following sections. Calorific values of the respective SVO blends were found by using the bomb calorimeter and are presented in Table 2.
Table 1

Specifications of gas analyser

\begin{tabular}{|c|c|}
\hline Measuring Gas & Maximum Range \\
\hline $\mathrm{CO}$ & $0-10(\%)$ \\
\hline $\mathrm{HC}$ & $0-20000(\mathrm{ppm})$ \\
\hline $\mathrm{CO}_{2}$ & $0-20(\%)$ \\
\hline $\mathrm{O}_{2}$ & $0-25(\%)$ \\
\hline $\mathrm{NO}_{\mathrm{x}}$ & $0-1000(\mathrm{ppm})$ \\
\hline
\end{tabular}

Fuel blends

Table 2

\begin{tabular}{|c|c|c|c|c|}
\hline \multirow{2}{*}{ Fuel } & $\begin{array}{c}\text { Diesel Proportion } \\
\text { (By Volume) }\end{array}$ & $\begin{array}{c}\text { SVO Proportion } \\
\text { (By Volume) }\end{array}$ & Fuel Blend & Higher Calorific value $\mathrm{kJ} / \mathrm{kg} K$ \\
\hline \multirow{3}{*}{$\begin{array}{c}\text { Diesel }+ \\
\text { Sunflower oil }\end{array}$} & Diesel 100\% & Sunflower oil 0\% & Pure Diesel & 42414 \\
\cline { 2 - 5 } & Diesel 75\% & Sunflower oil 25\% & SFVO 25 & 40702 \\
\cline { 2 - 5 } & Diesel 50\% & Sunflower oil 50\% & SFVO 50 & 38975 \\
\hline \multirow{2}{*}{$\begin{array}{c}\text { Diesel + } \\
\text { Rice Bran oil }\end{array}$} & Diesel 100\% & Rice Bran Oil 0\% & Pure Diesel & 42414 \\
\cline { 2 - 5 } & Diesel 75\% & Rice Bran Oil 25\% & RBVO 25 & 40118 \\
\cline { 2 - 5 } & Diesel 50\% & Rice Bran Oil 50\% & RBVO 50 & 37810 \\
\hline
\end{tabular}

Results for combustion of SVO blends with diesel in a commercial oil burner with main air supply

Table 3

\begin{tabular}{|c|c|c|c|c|c|c|c|c|}
\hline \multirow[b]{2}{*}{$\begin{array}{l}\text { Sl. } \\
\text { No }\end{array}$} & \multirow[b]{2}{*}{ Fuel } & \multirow{2}{*}{$\begin{array}{l}\text { Mass of the Fuel } \\
\text { Consumed (kg) }\end{array}$} & \multicolumn{2}{|c|}{ Temperature $\left({ }^{\circ} \mathrm{C}\right)$} & \multirow{2}{*}{$\begin{array}{c}\text { Rise in } \\
\text { Temperature } \\
\left({ }^{\circ} \mathrm{C}\right) \\
\end{array}$} & \multirow[b]{2}{*}{$\begin{array}{l}\text { Heat Input } \\
\qquad\left(Q_{i}\right) \mathrm{kJ}\end{array}$} & \multirow[b]{2}{*}{$\begin{array}{l}\text { Heat Output } \\
\quad\left(Q_{o}\right) \mathrm{kJ}\end{array}$} & \multirow[b]{2}{*}{$\begin{array}{c}\text { Efficiency } \\
(\eta) \%\end{array}$} \\
\hline & & & $\begin{array}{c}\text { Initial } \\
\left(T_{i}\right)\end{array}$ & $\begin{array}{c}\text { Final } \\
\left(T_{f}\right)\end{array}$ & & & & \\
\hline 1 & Diesel & 0.295 & 40 & 80 & 40 & 12512.1 & 4689 & 37.48 \\
\hline 2 & SFVO 25 & 0.440 & 40 & 80 & 40 & 17908.9 & 4689 & 26.18 \\
\hline 3 & SFVO 50 & 0.560 & 40 & 80 & 40 & 21826.0 & 4689 & 21.49 \\
\hline 4 & RBVO 25 & 0.408 & 40 & 80 & 40 & 16368.1 & 4689 & 28.65 \\
\hline 5 & RBVO 50 & 0.528 & 40 & 80 & 40 & 19963.7 & 4689 & 23.49 \\
\hline
\end{tabular}

3.1. Results of combustion of SVO blends with main air supply

$28 \mathrm{~kg}$ of water $\left(m_{w}\right)$ in the mini hot water generator shell is heated by firing different fuels as listed in Table 2, so that the temperature of water is increased from $40^{\circ} \mathrm{C}\left(T_{i}\right)$ to $80^{\circ} \mathrm{C}\left(T_{f}\right)$. Mass of the fuel in the fuel $\left(m_{f}\right)$ tank is weighed at the beginning and end of the heating process recorded $a s m_{i}$ and $\mathrm{m}_{\mathrm{f}}$ respectively.

The heat output $\left(Q_{o}\right)$ during the heating of water is calculated from the mass of water and temperature rise in water i.e., $Q_{o}=m_{w} C_{p}\left(T_{f}-T_{i}\right)$, kJ and the heat input is by fuel consumption and calorific value i.e., $\left(Q_{i}\right)=m_{f} . C V$, kJ. Finally, the efficiency $(\eta)$ of mini hot water generator is calculated as the ratio between $Q_{o}$ and $Q_{i}$.

The measurement and calculated results for the case of burning of fuels fired with main air supply alone using the commercial oil burner have been presented in Table 3 .

Fig. 2 depicts the comparison of thermal efficiency of SVO blends fired by a commercial oil burner with main air supply. The thermal efficiency is in general, maximum for diesel and it is $37.48 \%$. RBVO 25 and SFVO 25 blends have thermal efficiency of $28.65 \%$ and $26.18 \%$ respectively. RBVO 50 and SFV 50 blends have thermal efficiency of $23.49 \%$ and $21.49 \%$ respectively.

The thermal efficiency of the system is found to be low for all the blends of straight vegetable oils compared to the case of diesel. This may be due to the insufficient amount of air supplied, poor atomization of the fuel and high viscosity of the oil. Hence, a further study has been carried out to find the influence of additional air supply to the burner to improve the efficiency of the system when fired by SVO blends.

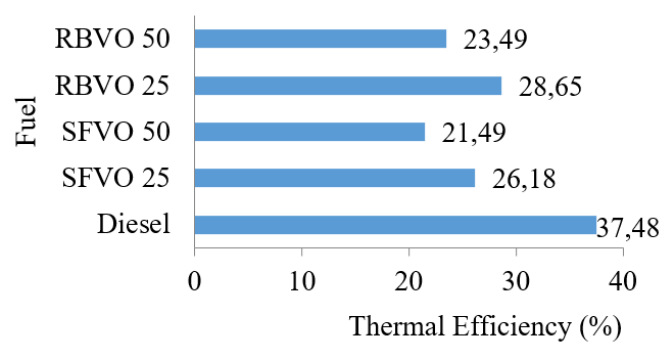

Fig. 2 Thermal efficiency of SVO blends fired by a commercial oil burner with main air supply

3.2. Results of combustion of SVO blends with main and additional air supply

The combustion of blends of RBVO and SFVO oils has been carried out with main and additional air supply (40\% and $80 \%$ additional air). The arrangement of additional air supply system is shown in Fig. 3.

The measurement and calculated results for the case of burning of fuels fired with main air and $80 \%$ additional air supply using the commercial oil burner have been presented in Table 4.

Fig. 4 presents the comparison of thermal efficiency of the system when fired with various SVO blends using main and additional air supply. The use of additional air supply increases the thermal efficiency; by improving the mixing of fuel and air molecules. It is clear that the improvement in thermal efficiency of the combustion system is more for SVO blends 
than that of diesel when the extra air is supplied. This may be due to the requirement of sufficient oxygen molecules for complete combustion in case of high viscous SVO blends.

The thermal efficiency of diesel increases from $37.48 \%$ to $39.48 \%$ and the percentage improvement in the efficiency is only $5.34 \%$. RBVO 25 and SFVO 25 blends have thermal efficiency of $33.98 \%$ and $31.31 \%$ and the corresponding percentage increase in the efficiency is $18.6 \%$ and $19.59 \%$ respectively. Similarly, RBVO 50 and SFVO 50 blends have thermal efficiency of $30.7 \%$ and $25.93 \%$ and the corresponding percentage increase in the efficiency is $30.69 \%$ and $20.66 \%$ respectively.

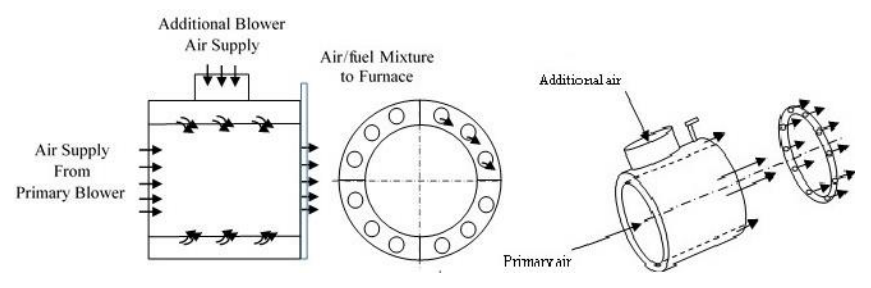

Fig. 3 Additional air supply system

Results for combustion of SVO blends with main and $80 \%$ additional air supply

\begin{tabular}{|c|c|c|c|c|c|c|c|c|}
\hline \multirow[b]{2}{*}{ Sl.No } & \multirow[b]{2}{*}{ Fuel } & \multirow{2}{*}{$\begin{array}{l}\text { Mass of the Fuel } \\
\text { Consumed } \\
(\mathrm{kg})\end{array}$} & \multicolumn{2}{|c|}{ Temperature $\left({ }^{\circ} \mathrm{C}\right)$} & \multirow{2}{*}{$\begin{array}{c}\text { Rise in } \\
\text { Temperature } \\
\left({ }^{\circ} \mathrm{C}\right)\end{array}$} & \multirow[b]{2}{*}{$\begin{array}{l}\text { Heat Input } \\
\qquad\left(Q_{i}\right) \mathrm{kJ}\end{array}$} & \multirow[b]{2}{*}{$\begin{array}{l}\text { Heat Output } \\
\qquad\left(Q_{o}\right) \mathrm{kJ}\end{array}$} & \multirow[b]{2}{*}{$\begin{array}{c}\text { Efficiency } \\
(\eta) \%\end{array}$} \\
\hline & & & $\begin{array}{c}\text { Initial } \\
\left(T_{i}\right)\end{array}$ & $\begin{array}{c}\text { Final } \\
\left(T_{f}\right)\end{array}$ & & & & \\
\hline 1 & Diesel & 0.280 & 40 & 80 & 40 & 11875.9 & 4689 & 39.48 \\
\hline 2 & SFVO 25 & 0.368 & 40 & 80 & 40 & 14978.3 & 4689 & 31.31 \\
\hline 3 & SFVO 50 & 0.464 & 40 & 80 & 40 & 18084.4 & 4689 & 25.93 \\
\hline 4 & RBVO 25 & 0.344 & 40 & 80 & 40 & 13800.5 & 4689 & 33.98 \\
\hline 5 & RBVO 50 & 0.404 & 40 & 80 & 40 & 15275.2 & 4689 & 30.70 \\
\hline
\end{tabular}

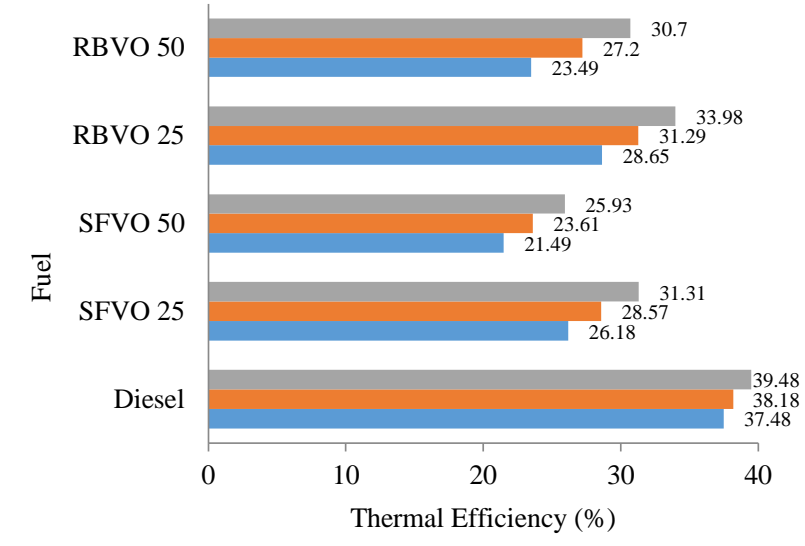

Commercial Burner With $80 \%$ Additional Air Commercial Burner With 40\% Additional Air - Commercial Burner Without Additional Air

Fig. 4 Comparison of thermal efficiency of SVO blends fired by a commercial oil burner with and without additional air supply

The extra oxygen supplied in the form of additional air supply helps in providing better mixing with the fuel and improving the combustion. Especially the efficiency of SVO blend with higher percentage improves more than that of lower percentage in the blend. The unburned fuel molecules in the combustion products due to incomplete combustion get combusted with the additional air supply. As more numbers of unburned molecules are present in the combustion products of higher percent percentage SVO (50\%), the improvement in the efficiency is also more.

\section{Emissions}

\subsection{Carbon monoxide emission}

Fig. 5 shows the levels of carbon monoxide emission in the exhaust gases from the mini hot water generator fired with diesel, SFVO 25, SFVO 50, RBVO 25 and RBVO 50.The measured values for $\mathrm{CO}$ emission during the combustion of fuels using main air alone and with the use $80 \%$ of additional air supply have been compared.

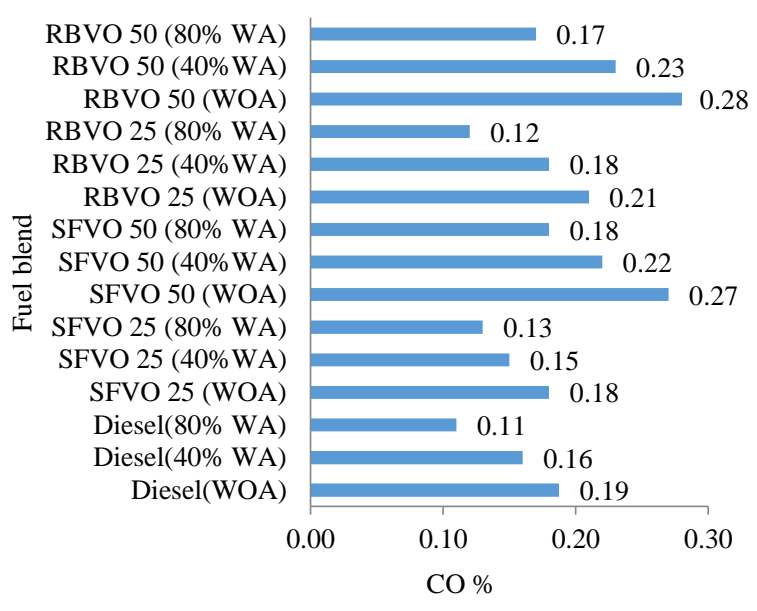

Fig. 5 Carbon monoxide emission for various fuel blends

$\mathrm{CO}$ emission significantly increases with the addition of SVO in the fuel blend at higher percentage when the combustion is carried out without additional air supply. This may be due to incomplete combustion of viscous vegetable oil, insufficient $\mathrm{O}_{2}$ and poor mixing of oxygen and oil. The $\mathrm{CO}$ emission is slightly higher for rice bran oil blend than that of sunflower oil.

The results for additional air supply (80\%) show that the $\mathrm{CO}$ emission is slightly lower for rice bran oil blend than that of sunflower oil. It may be due to the better mixing of air and fuel droplet and combustion of rice bran oil with the supply of additional air. It also reduces the level of $\mathrm{CO}$ emission by about $40 \%$ in all the cases. This higher percentage may be due to the conversion of carbon mono-oxide molecule into carbon di oxide and the dilution of concentrtion due to volume of additional air in the combustion products.

\subsection{Carbon dioxide emission}

$\mathrm{CO}_{2}$ emission is less than that of diesel for all the fuel blends of sunflower and ricebran oil. Further, the percentage of $\mathrm{CO}_{2}$ emission is found to decrease for all the blends, when the additional air supply is introduced. But this drop in $\mathrm{CO}_{2}$ is due to conversion of unburnt fuel molecules as well as excess air 
supplied in the form of additional air to the combustion system. This is due to dilution of gas mixure, where the concentration of $\mathrm{CO}_{2}$ decreases with excess air.

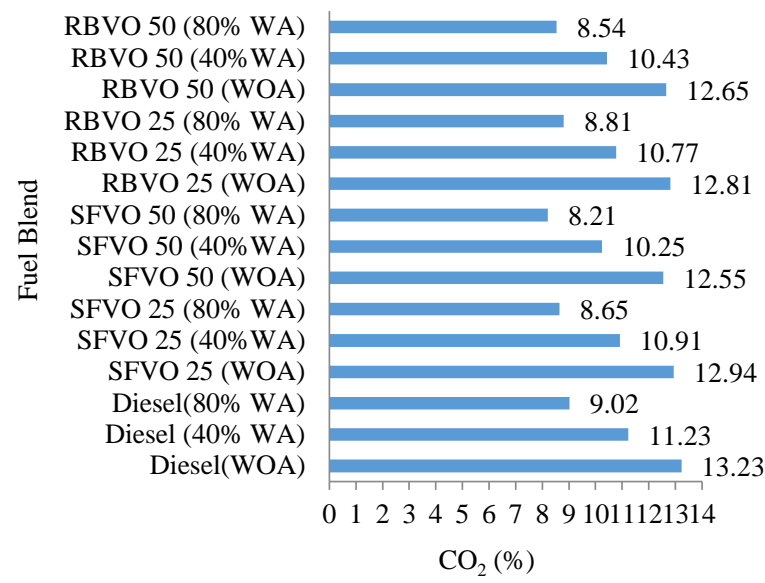

Fig. 6 Carbon dioxide emission for various fuel blends

\subsection{Nitrogen oxides emission}

The of nitrogen oxide emissions have been measured for burning of different blends of SFVO and RBVO with diesel, fired with main and additional air supply and the results are shown in Fig. 7. The $\mathrm{NO}_{\mathrm{x}}$ emission is higher for diesel than SVO blends. Figure shows the influence of blend on the nitrogen oxides emission.

The emission of nitrogen oxides is higher for diesel for both the cases, with and without the supply of additional air and the levels have been recorded as $52 \mathrm{ppm}$ and $48 \mathrm{ppm}$ respectively. For SFVO 25, the $\mathrm{NO}_{\mathrm{x}}$ emission is slightly lower than that of diesel and it is $38 \mathrm{ppm}$ and $39 \mathrm{ppm}$ for the cases, with and without additional air supply respectively. Further higher percentage of oil in the $50 \%$ blend decreases the NOx emission up to 24 and $22 \mathrm{ppm}$. $\mathrm{NO}_{\mathrm{x}}$ emission for rice bran oil is quite higher than that of sunflower oil blends.

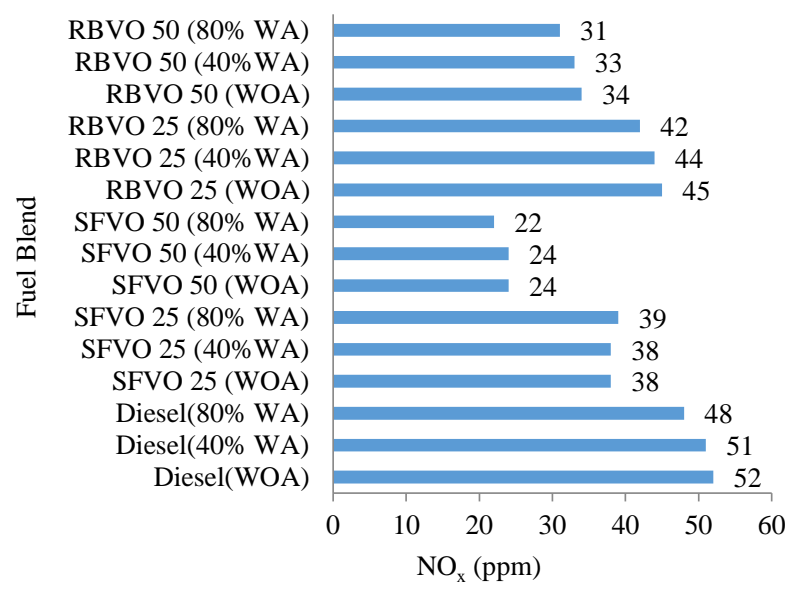

Fig. 7 Nitrogen oxides emission for various fuel blends

The $\mathrm{NO}_{\mathrm{x}}$ emission of RBVO 25 blend is $45 \mathrm{ppm}$ and $42 \mathrm{ppm}$ for WOA and WA respectively. The emission further decreases to $34 \mathrm{ppm}$ for the case, without additional air and 31 ppm for the case, with additional air, for RBVO 50. The lower in $\mathrm{NO}_{\mathrm{x}}$ for the case of additional air supply is due to more amount of nitrogen and oxygen present in the excess air and lower furnace temperature.

\section{Conclusions}

In the present work, an experimental study has been carried out to improve the performance of mini hot water generator using additional air supply. The following are the conclusions from the present study. The additional air supply with the main air supply enhances the combustion performance, leading to increase in thermal efficiency and decrease in $\mathrm{CO}$ emission.

1. The efficiency of mini hot water generator fired with diesel increases from $37.48 \%$ to $39.48 \%$ when $80 \%$ additional air is supplied.

2. The efficiency of mini hot water generator fired with SFVO 25 and RBVO 25 increases by $19.59 \%$ and $18.6 \%$ respectively when the burner is supplied with $80 \%$ additional air supply and it is $20.66 \%$ and $30.69 \%$ rise for SFVO 50 and RBVO 50 respectively, fired with additional air supply.

3. The $\mathrm{CO}$ emission is almost in the same range that of diesel. But $\mathrm{CO}_{2}$ decreases by $34.6 \%$ and $33.4 \%$ for $25 \%$ blends of straight sunflower oil and rice bran oil blend when additional air is supplied. For $50 \%$ blends of straight sunflower oil and rice bran oil blend, the $\mathrm{CO}_{2}$ emission decreases by $37.9 \%$ and $35.4 \%$ respectively. The level of $\mathrm{NO}_{\mathrm{x}}$ emission decreases for SVO blended with diesel and it is in the range of 22 to $52 \mathrm{ppm}$.

\section{References}

1. Raslavičius, L.; Keršys, A.; Starevičius, M.; Sapragonas, J.; Bazaras, Z. 2014. Biofuels, sustainability and the transport sector in Lithuania, Renewable and Sustainable Energy Reviews 32 :328-346. https://doi.org/10.1016/j.rser.2014.01.019.

2. Raslavičius, L.; Strakšas, A. 2011. Motor BiofuelPowered CHP Plants-A Step towards Sustainable Development of Rural Lithuania, Technological and Economic Development of Economy 17, 1: 189-205. https://doi.org/10.3846/13928619.2011.560639.

3. Zhou, A.; Thomson, E. 2009. The development of biofuels in Asia, Applied Energy 86: S11-S20. https://doi.org/10.1016/j.apenergy.2009.04.028.

4. Phan, A.N.; Phan, T.M. 2008. Biodiesel production from waste cooking oils, Fuel 87: 3490-3496. https://doi.org/10.1016/j.fuel.2008.07.008.

5. Jayed, M.H.; Masjuki, H.H.; Saidur, R.; Kalam, M.A.; Jahirul, M.I. 2009. Environmental aspects and challenges of oilseed produced biodiesel in Southeast Asia, Renewable and sustainable energy reviews 13: 2452-2462. https://doi.org/10.1016/j.rser.2009.06.023.

6. Sanz Requena, J.F.; Guimaraes, A.C; Quiros Alpera, S.; Relea Gangas, E.; Hernandez-Navarro, S.; Navas Gracia, L.M.; Martin-Gil, J.; Fresneda Cuesta, H. 2011. Life Cycle Assessment (LCA) of the biofuel production process from sunflower oil, rapeseed oil and soybean oil, Fuel Processing Technology 92: 190-199. https://doi.org/10.1016/j.fuproc.2010.03.004.

7. Demirbas, A. 2009. Political, economic and environmental impacts of biofuels: A review, Applied Energy 86: $108-117$. https://doi.org/10.1016/j.apenergy.2009.04.036.

8. San Jose Alonso, J.; Lopez Sastre, J.A.; RomeroAvila, C.; Lopez, E. 2008. A note on the combustion of 
blends of diesel and Soya, sunflower and rapeseed vegetable oils in a light boiler, Biomass and Bioenergy 3: $880-886 \mathrm{~J}$.

https://doi.org/10.1016/j.biombioe.2008.01.007.

9. Singh, R.K.; Padhi, S.K. 2009. Characterization of jatropha oil for the preparation of biodiesel, Natural product Radiance 8, 2: 127-132.

http://nopr.niscair.res.in/handle/123456789/4046.

10. Yathish, K.V.; Omkaresh, B.R.; Suresh, R. 2013. Biodiesel Production from Custard Apple Seed (Annona Squamosa) Oil and its Characteristics Study, International Journal of Engineering and Technology 2, 5: 3136.

11. Maran, P; Arumugam, K. 2015. Influence of Ethanol and Di-Ethyl Ether Addition on Fuel Properties of Sunflower Oil Methyl Ester, Applied Mechanics and Materials 787: 736-740. http://doi:10.4028/www.scientific.net/AMM.787.736.

12. Esteban, B.; Riba, J.R.; Baquero, G.; Rius, A.; Puig, R. 2012. Temperature dependence of density and viscosity of vegetable oils, Biomass and Bio Energy, 42:164171. https://doi.org/10.1016/j.biombioe.2012.03.007.

13. Kang, S.B.; Kim, J.J.; Im, Y. H. 2013. An experimental investigation of a direct burning of crude Jatropha oil (CJO) and pitch in a commercial boiler system, Renewable Energy 54: 8-12.

https://doi.org/10.1016/j.renene.2012.11.006.

14. Glaude, P.A.; Fournet, R.; Bounaceur, R.; Molière, M. 2010. Adiabatic flame temperature from biofuels and fossil fuels and derived effect on $\mathrm{NO}_{\mathrm{x}}$ emissions, Fuel Processing Technology 91: 229-235. https://doi.org/10.1016/j.fuproc.2009.10.002.

15. Chong, C.T.; Hochgreb, S. 2014. Spray flame structure of rapeseed biodiesel and Jet-A1 fuel, Fuel 115: 551558. https://doi.org/10.1016/j.fuel.2013.07.059.

16. Czisch, C.; Fritsching, U. 2008. Atomizer design for viscous-melt atomization, Materials Science and Engineering, 477: 21-25. http://dx.doi.org/10.1016/j.msea.2007.06.087.

17. Fan, Y.; Hashimoto, N.; Nishida, H.; Ozawa, Y. 2014. Spray characterization of an air-assist pressure-swirl atomizer injecting high-viscosity Jatropha oils, Fuel, 121: 271-283. https://doi.org/10.1016/j.fuel.2013.12.036.

18. Raslavičius, L.; Bazaras, Z. 2010. Ecological assessment and economic feasibility to utilize first generation biofuels in cogeneration output cycle -The case of Lithuania, Energy 35,9: 3666-3673. https://doi.org/10.1016/j.energy.2010.05.011.

19. Vaitilingom, G.; Perilhon, C.; Liennard, A.; Gandon, M. 1998. Development of rape seed oil burners for drying and heating, Industrial Crops and Products 7: 273279. https://doi.org/10.1016/S0926-6690(97)00058-7.

20. Yao, S.; Zhang, J.; Fang, T. 2012. Effect of viscosities on structure and instability of sprays from a swirl atomizer, Experimental Thermal and Fluid Science 39: 158166. https://doi.org/10.1016/j.expthermflusci.2012.01.020.

21. San Jose' Alonso, J.; Lo'pez Sastre, J.A.; RomeroA'vila, C.; Lo'pez Romero, E.J. 2006. Combustion of rapeseed oil and diesel oil mixtures for use in the production of heat energy, Fuel Processing Technology 87: $97-102$.

https://doi.org/10.1016/j.fuproc.2005.07.004

22. Bazooyar, B.; Ghorbani, A.; Shariati, A. 2011. Combustion performance and emissions of petrodiesel and biodiesels based on various vegetable oils in a semi industrial boiler, Fuel 90:3078-3092.

https://doi.org/10.1016/j.fuel.2011.05.025.

23. Ghorbani, A.; Bazooyar, B.; Shariati, A.;Jokar, S.M.; Ajami, H.; Naderi, A. 2011. A comparative study of combustion performance and emission of biodiesel blends and diesel in an experimental boiler, Applied Energy 88: 4725-4732.

https://doi.org/10.1016/j.apenergy.2011.06.016.

24. Dizayi, B.; Li, H.; Hadavi, S.A.; Tomlin, A.S. 2015. Particulate Matter Emissions from a Heavy Duty Vehicle Fuelled By Petroleum Diesel and Used Cooking Oil Blends, Proceedings of the European Combustion Meeting, Energy Research Institute, University of Leeds, Leeds, UK.

25. Daho, T.; Vaitilingom, G.; Sanogo, O. 2009. Optimization of the combustion of blends of domestic fuel oil and cottonseed oil in a non-modified domestic boiler, Fuel 88: 1261-1268.

https://doi.org/10.1016/j.fuel.2008.12.021.

K. Arumugam, P. Maran, K. Aravindhan, T. Sornakumar

EFFECT OF ADDITIONAL AIR SUPPLY FOR COMBUSTION OF STRAIGHT VEGETABLE OIL BLENDS ON PERFORMANCE OF MINI HOT WATER GENERATOR

S u m m a r y

This paper presents the results of an experimental investigation on the efficient combustion of blends of Straight Vegetable Oil (SVO) with diesel, fired in a non-commercial hot water generator. The high viscosity and poor atomization characteristics of straight vegetable oil lower the combustion and thermal efficiency of the system. An additional air supply system has been used to provide sufficient amount of air into the furnace to improve the mixing of fuel droplets and oxygen in the air. Thermal efficiency and emission characteristics of $25 \%$ and $50 \%$ blends of straight sunflower oil and rice bran oil with diesel have been studied with and without additional air supply. Thermal efficiency of the hot water generator has been found to be increased when the quantity of additional air supply is increased. Moreover, the emissions of $\mathrm{CO}$ and $\mathrm{HC}$ have been reduced by the additional air supply.

Keywords: straight vegetable oil, blend, diesel, additional air supply, combustion, emission.

Received December 27, 2017

Accepted April 18, 2018 